\begin{tabular}{l|l|l|l|l}
\hline Volume 2 & Nomor 1 & Mei (2021) & DOl: http://dx.doi.org/10.52423//kps.v2i1.18175 & 86-96 \\
\hline
\end{tabular}

\title{
PERILAKU MENYIMPANG DAN REMEDI SOSIAL STUDI SMA SWASTA OIKUMENE KENDARI KEL. MANDONGA KEC. MANDONGA
}

\author{
Suri Yati ${ }^{1}$, Muhammad Arsyad ${ }^{2}$, Sarmadan ${ }^{3}$ \\ 123Jurusan Sosiologi FISIP Universitas Halu Oleo, Kendari, Indonesia \\ 1Email korespondensi: suri.yf15@gamail.com
}

\begin{abstract}
ABSTRAK
Tujuan penelitian ini adalah untuk mengetahui bagaimana remedi sosial di SMA Swasta Oikimene Kendari. Pendekataan yang digunakan adalah pendekataan kualitatif dengan metode deskriptif. Hasil penelitian menunjukkan bahwa remedi sosial yang diakukan di SMA Swasta Oikumene Kendari sudah berjalan dengan baik tapi tidak sepenuhnya efektif. Hal ini dikarenakan masih ada beberapa siswa yang melakukan perilaku menyimpang seperti datang terlambat ke sekolah, absen sekolah, bolos saat jam pelajaran, merokok di lingkungan sekolah, mencuri, main judi bahkan ada yang membawa obat terlarang. Faktor penyebab siswa siswa melakukan perilaku menyimpang yaitu faktor keluarga, faktor sekolah atau teman sepermainan, faktor masyarakat. Remedi sosial yang dilakukan pihak sekolah untuk meminimalisir perilaku menyimpang siswa yaitu dengan upaya preventif dengan mengadakan sosialisasi tentang pentingnya tata tertib pada tahun ajaran baru, kegiatan keagamaan dan kerja sama dengan orang tua. Upaya represif yaitu memeberi nasehat, surat panggilan orang tua, hukuman atau sanksi.
\end{abstract}

Kata Kunci: Siswa, Perilaku menyimpang, Remedi Sosial

\begin{abstract}
The purpose of this study was to determine how the social remedy in Oikimene Kendari Private High School. The approach used is a qualitative approach with a descriptive method. The results showed that the social remedies carried out at the Oikumene Kendari Private High School were running well but not fully effective. This is because there are still some students who have deviant behavior such as arriving late to school, absent from school, skipping class during class hours, smoking in the school environment, stealing, gambling and some even carrying illegal drugs. Factors that cause students to deviate from behavior are family factors, school factors or playmates, community factors. Social remedies carried out by the school to minimize deviant behavior among students, namely by means of preventive efforts by holding outreach on the importance of discipline in the new academic year, religious activities and
\end{abstract}


cooperation with parents. Repressive measures, namely giving advice, summons for parents, punishment or sanctions.

Keywords: Students, Deviant Behavior, Social Remedy

\section{PENDAHULUAN}

Pada dasarnya semua manusia cenderung bersifat konformitas yang merupakan bentuk interaksi yang didalamnya seseorang berperilaku terhadap orang lain sesuai dengan harapan kelompok atau masyarakat dimana ia tinggal, dengan cara menaati norma-norma dan nilai-nilai masyarakat tersebut. Namun, dalam kenyataan, meskipun suatu masyarakat telah berusaha agar setiap anggotanya berperilaku sesuia dengan yang diharapkan, kita selalu menjumpai adanya anggota masyarakat dengan individu, individu dengan kelompok dan kelompok dengan kelompok. Didalam hubungan tersebut, individu atau kelompok melakukan interaksi, baik formal maupun tidak formal, langsung atau tidak langsung. Dalam interaksi sosial terjadi hubungan timbal balik yang melibatkan yang berperilaku menyimpang (Chit, 2020). Suatu perilaku dikatakan menyimpang (Deviance) apabila tidak sesuai dengan nilainilai dan norma-norma yang berlaku dalam masyarakat. Contoh perilaku menyimpang yang sering terjadi dalam masyarakat antara lain merokok, mencuri, membunuh, menganiaya, menculik, berkelahi, menodong, mengedarkan obat-obat terlarang, mabuk-mabukkan, korupsi, memalsukan uang, bolos sekolah, bermain judi, dan perilaku seks bebas (Suhaida dkk., 2018).

Dalam masa peralihan dan perkembangan baik fisik maupun mental, remaja seringkali menghadapi permasalahan-permasalahan tersendiri baik baik yang berasal dari dalam diri sendiri (Factor intern) maupun yang berasal dari lingkungan (factor ekstern). Menurut Pikunas dalam Yusuf (2007 : 184) menyatakan bahwa : Dalam budaya Amerika, periode remaja ini dipandang sebagai masa "Strom \& Stress" frustasi dan penderitaan, konflik dan krisis penyesuaian, mimpi dan melamun tentang cinta, dan perasaan teralienasi (tersisihkan) dari kehidupan sosial budaya orang dewasa.

Horton dan Hunt (1984 : 65) menyatakan, "perilaku menyimpang adalah setiap perilaku yang dinyatakan sebagai suatu pelanggaran terhadap norma- 
norma kelompok masyarakat. Seseorang yang telah melanggar norma-norma masyarakat disebut juga sebagai suatu perilaku menyimpang. Setiadi (2011 : 188) menyatakan, "perilaku menyimpang pada dasarnya adalah semua perilaku manusia yang dilakukan baik secara individual maupun secara kelompok tida sesuai dengan nilai dan norma yang berlaku dalam kelompok tersebut".

Lebih lanjut, Bruce J. Cohen (dalam Muin 2006 : 153), "membatasi perilaku menyimpang sebagai setiap perilaku yang tidak berhasil menyesuaikan diri dengan kehendak masyarakat atau kelompok tertentu dalam masyarakat". Siswa merupakan bagian dari remaja yang tidak lepas dari permasalahan remaja pada umumnya, apalagi dewasa ini pengaruh globalisasi, modernisasi, perubahan sosial budaya dalam masyarakat, dan perkembangan ilmu pengetahuan dalam teknologi (IPTEK) yang tidak saja membawa dampak positif tetapi juga membawa dampak negatif, sehingga apabila siswa yang notabene sebagai pelajar tidak dapat menfilter diri dengan baik dari pengaruhpengaruh yang masuk maka dapat mengakibatkan dirinya terjerumus dan terpengaruh pada hal-hal yang negatif yang pada akhirnya akan berakibat buruk bagi dirinya sendiri dan dapat merusak masa depan diri mereka sendiri serta dapat merugikan bagi lingkungan sekitarnya. Dampak negatif dari globalisasi yang tidak bisa difilter oleh para siswa akan membuat perubahan dalam perilaku siswa yang cenderung menjadi kenakalan remaja. Perilaku menyimpang atau kenakalan remaja adalah suatu tindakan yang bertentangan dengan norma-norma hukum, kebiasaan, atau adat istiadat yang berlaku dimana orang tersebut tinggal.

Sekolah SMA Swasta Oikumene Kendari adalah suatu organisasi sekolah yang saat ini menjadi tempat kontak sosial (Social Contact) dan tempat berkomunikasi sesama teman sebaya, dengan usia adolesen berada pada usia 13-28 tahun. Mereka memiliki tata cara atau prosedur yang diciptakan untuk mengatur hubungan sesama siswa di sekolah, siswa dengan guru, bahkan hubungan guru dengan guru. Sekolah sebagai lembaga pendidikan melakukan kontak sosial yang menyebabkan terjadinya sosialisasi antara satu siswa dengan siswa lainnya. Pertukaran norma dan nilai-nilai keluarga yang dibawa oleh masing-masing siswa ke sekolah menyebabkan satu sama lain membentuk 
tanggapan terhadap peristiwa kontak sehari-hari mulai dari cerita pribadi hingga keluarga dengan rasa ingin tahu yang besar.

Salah satu sekolah yang berada di bawah Yayasan Pendidikan Kristen Gepsultra. Keberadaan sekolah ini telah memberikan kontribusi terhadap peningkatan mutu pendidikan di Sulawesi Tenggara, sejak didirikan tahun 1980. Sekolah ini telah menghasilkan lulusan kurang dari 5000 orang dan 95 persen melanjutkan pendidikan kejenjang perguruan tinggi baik negeri maupun swasta. Dalam memasuki tahun ajaran 2011/2012, SMA Swasta Oikumene telah berkomitmen untuk melaksakana proses pembelajaran lebih menekankan pada pendidikan karakter, yang kemudian menghasilakn siswa yang berkualitas secara akademik, sikap/etik, dan imtaq.

Di sekolah SMA Swasta Oikumene Kendari sering terjadi perilaku menyimpang yang dilakukan oleh siswa antara lain merokok di lingkungan sekolah, bolos atau cabut saat jam pelajaran, melawan guru, mencuri, terlambat ke sekolah, tidak memakai atribut lengkap sekolah, berambut panjang dan pirang, bermain ke warnet, serta membawa obat terlarang. Siswa yang melakukan perilaku menyimpang biasanya mempunyai latar belakang keluarga yang broken home/keluarganya miskin dan latar belakang keluarganya yang sibuk mencari nafkah. Upaya mencapai tujuan hidup, menyebabkan manusia akan mengembangkan perilaku yang mendukung perannya.

Dalam kasus perilaku menyimpang diatas perilaku menyimpang SMA Swasta Oikumene Kendari telah melakukan berbagai cara agar siswa tidak mengulangi lagi perbuatannya. Beberapa siswa dari hasil wawancara menagatakan bahwa mereka sering kali mengulangi perilaku menyimpang karena ajakan teman-temannya yang lain, faktor lingkungan dan kemauan sendiri, karena keberadaan SMA Swasta Oikumene Kendari berada di tengahtengah rumah masyarakat. Dalam mengatasi perilaku menyimpang ini pihak sekolah melalui guru BK (Bimbingan Konseling), Guru Mata Pelajaran, Wali Kelas, bidang kesiswaan dan Kepala Sekolah mengadakan remedi sosial, namun demikian walaupun telah dilakukan remedi sosial, siswa ditemukan masih tetap melakukan perilaku menyimpang dan cenderung dilakukan berkali-kali. 


\section{METODE}

Dalam penelitian ini penedekatan yang dilakukan adalah melalui pendekatan kualitatif. Artinya data yang dikumpulkan bukan berupa angkaangka melainkan data tersebut berasal dari naskah wawancara, catatan lapangan, dokumen pribadi, dan dokumen resmi lainnya. Dengan lokasi penelitian di SMA Swasta Oikumene Kendari. Informan penelitian i ni adalah Kepala Sekolah, Wali atau bagian Kesiswaan, Siswa, dan Orang Tua Siswa. Tujuan menggunakan metode ini adalah untuk mengambarkan, mengungkapkan atau menyajikan apa adanya tentang perilaku menyimpang dan remedi sosial siswa SMA Swasta Oikumen Kendari. Dalam penelitian ini, peneliti akan melakukan wawancara terbuka atau tidak standar dengan menggunakan bantuan metode wawancara yang telah disusun sebelumnya. Dengan demikian, wawancara dapat terarah pada informasi yang diperlukan dalam penelitian. Dalam hal ini cara pengumpulan data yang dilakukan adalah mengamati secara langsung terhadap objek penelitian yaitu siswa yang bermasalah dan mencatat gejala-gejala pada objek penelitian. Adapun alat yang digunakan untuk pengumpulan data adalah panduan wawancara, panduan observasi, buku catatan dan arsip-arsip.

\section{HASIL DAN PEMBAHASAN}

\section{Bentuk-Bentuk Perilaku Menyimpang Siswa}

Dalam sebuah instansi seperti sekolah tidak menutup kemungkinan dapat terjadi perilaku menyimpang yang dilakukan oleh siswa. Perilaku menyimpang yang dimaksud adalah pelanggaran terhadap tata tertib ini dibuat untuk mengontrol perilaku siswa agar bertindak tertib dan teratur serta disiplin sesuai dengan nilai dan norma yang ada di sekolah. Begitu juga hal sekolah SMA Swasta Oikumene Kendari masih ada siswa yang melakukan perilaku menyimpang.

Di sekolah khususnya di SMA Swasta Oikumene Kendari penyimpangan juga dapat terjadi dikatakan menyimpang apabia siswa melanggar tata tertib yang telah ditetapkan di sekolah. Siswa melakukan penyimpangan karena tidak dapat menyesusikan diri dengan lingkungan sekolah. Senada dengan yang dikatakan Bruce J. Cohen (dalam Setiadi 2011 : 188) perilaku menyimpang 
sebagai setiap perilaku yang tidak berhasil menyesuaikan diri dengan kehendak masyarakat atau kelompok tertentu dalam masyarakat. Dalam hal ini siswa dapat menyesuaikan diri dengan lingkungan sekolah terutama dengan tata tertib yang ada di SMA Swasta Oikumene Kendari.

Dari hasil penelitian yang dilakukan peneliti di SMA Swasta Oikumene Kendari dengan cara observasi, wawancara dan studi dokumentasi peneliti menemukan beberapa bentuk perilaku menyimpang yang terjadi di SMA Swasta Oikumene Kendari yaitu penyimpangan primer datang terlambat ke sekolah, absen sekolah, bolos saat jam pelajaran berlangsung. Perilaku menyimpang sekunder diantaranya merokok di lingkungan sekolah, mencuri dan membawa obat terlarang. Apabila ada siswa yang melakukan perilaku menyimpang atau melanggar tata tertib yang dibuat oleh sekolah, maka akan diberikan sanksi atau hukuman sesuai dengan tingkat pelanggaran atau perilaku menyimpang yang dilakukan siswa. Sanksi atau hukuman ini adalah salah satu bentuk remedi sosial yang dilakukan agar siswa yang melakukan perilaku menyimpang bisa jera dan tidak melakukannya lagi di kemudian hari. Namun terkadang apa yang diharapkan tidak sesuai dengan kenyataan.

\section{Faktor Penyebab}

Perilaku menyimpang yang dilakukan siswa SMA Swasta Oikumene Kendari tidak terlepas dari panggkal permasalahan yang menyebabkannya. Ada dua faktor yang menyebabkan siswa melakukan perilaku menyimpang yaitu faktor internal dan faktor eksternal. Menurut Mustaqim (2010 : 139). "sebab-sebab internal iyalah sebab-sebab yang berpangkal dari kondisi si murid itu sendiri. Faktor eksternal hang di kemukakan Mustaqim (2010 : 140), “sebabsebab eksternal berpangkal dari keluarga, pergaulan, slah asuh atau pengalaman hidup yang tak menyenangkan. “

Dari hasil wawancara dengan beberapa guru dan siswa yang bermasalah, penyebab siswa berperilaku menyimpang di SMA Swasta Oikumene Kendari di sebabkan oleh keluarga, ajakan teman, pergaulan dan lingkungan masyarakat. Dari hasil penelitian ada tiga faktor yang menyebabkan terjadinya perilaku menyimpang siswa di SMA Swasta Oikumene Kendari yaitu :

a. Faktor Keluarga

Keluarga adalah wadah dari permulaan pembentukan pribadi serta tumpuhan dasar fundamental bagi perkembangan dan pertumbuhan 
anak. Lingkungan keluarga secara potensial dapat membentuk pribadi anak menjadi hidup secara bertanggung jawab, apabila usaha pendidikan ini gagal, maka tertentuk seorang anak yang cenderung melakukan tindakan-tindakan yang bersifat kriminal. Itulah sebabnya mengapa keluarga dapat berperan dalam membentuk kepribadian yang menyimpang.

b. Faktor Sekolah

Sekolah adalah suatu lingkungan pendidikan yang secara garis besar masih bersifat formal. Anak remaja yang masih duduk di bangku SLTP maupun SLTA pada umumnya meraka yang menghabiskan waktu mereka selama tujuh jam di sekolah tiap hari, jadi jangan heran bila lingkungan sekolah sangat berpengaruh terhadap perkembagan moral anak.

c. Masyarakat

Masyarakat adalah lingkungan yang terluas bagi remaja dan sekaligus banyak menawarkan pilihan. Pada lingkungan inilah remaja dihadapkan berbagai bentuk kenyataan yang ada dalam kehidupan masyarakat yang berbeda-beda, apalagi dasarwasa terkhir ini perkembangan moral kemajuan ilmu pengetahuan dan teknologi berkembang dengan pesat, sehingga membawa perubahan-perubahan yang sangat berarti tetapi juga timbul masalah yang mengejutkan. Maka dalam situasi itulah yang menimbulkan melemahnya norma-norma dan nilai-nilai masyarakat yang mana kurang landasan agamanya, dan masyarakat yang acuh terhadap lingkungan yang ada di sekitarnya.

Dari hasil wawancara dan observasi ditemukan bahwa penyebab siswa melakukan perilaku menyimpang itu karna faktor keluarga salah satunya broken home kurang kasih sayang dari orang tua mengakibatkan siswa berperilaku menyimpang, faktor sekoah atau teman sepergaulan ajakan teman untuk melakukan perilaku menyimpang seprti bolos dan lingkungan masyarakat atau teman bergaul seperti salah satu siswa yang pergaulannya cenderung bebas karena faktor lingkungan iya tinggal.

3. Remedi Sosial 
Remedi sosial dalam lingkungan sekolah dapat dilaksanakan dengan melihat latar belakang siswa pada saat melakukan perilaku menyimpang. Kesadaran akan tata tertib sekolah tidak akan tercipta begitu saja tanpa usaha dan peran dari sekolah dan terencana untuk mengarahkan anak mencapai tujuan pendidikan anak yang beriman dan bermoral. Siti Hajar dan Abdula Hadi (2009) melihat remedi sosial sebagai serangkaian tindakan 'memperbaiki' keadaan sosial yang mempunyai dampak negatif terhadap kesejahteraan hidup masyarakat. Sederhanya, remedi sosial sebagai bentuk intervensi perilaku siswa untuk tertib. Tujuannya untuk mencegah perilaku yang bertentangan dengan keinginan bersama.

Remedi sosial yang dilakukan oleh pihak sekolah SMA Swasta Oikumene Kendari berupa upaya preventif dan represif. Upaya preventif yang dilakukan pihak sekolah yaitu berupa pembinaan dan sosialisasi tata tertib sekolah. Tujuannya adalah untuk mencegah terjadinya perilaku menyimpang di Sma Swasta Oikumene Kendari agar selalu dalam keadaan kondusif sebagaimana yang di katakan oleh Setiadi (2011), bahwa upaya preventif adalah segala bentuk upaya sosial yang berupaya pencegahan atas perilaku menyimpang (Deviation) agar kehidupan sosial tetap kondusif. Upaya represif juga dilakukan pihak sekolah agar siswa kembali berperilaku sesuai dengan aturan tata tertib. Hal ini sesuai yang dikemukakan Setiadi (2011), bahwa upaya secara represif adalah bentuk upaya sosial yang bertujuan untuk mengembalikan kekacauan sosial atau mengembalikan situasi deviasi menjadi keadaan kondusif kembali.

Dari hasil wawancara dan observasi peneliti menemukan ada beberapa cara remedi sosial yang dilakukan pihak sekolah SMA Swasta Oikumene Kendari untuk menanggulangi perilaku menyimpang yaitu dengan adanya sosialisasi tentang pentingnya tata tertib sekolah. Sosialisasi kepada siswa dilakukan ketika tahun ajaran baru dimulai. Sosioalisasi ini merupakan cara yang dilakukan untuk mencegah terjadinya penyimpangan tata tertib oleh siswa. Kegiatan keagamaan, guru agama selalu membimbing siswanya untuk taat kepada agama yang dianut masing-masing siswa sehingga dengan taat beragama siswa akan 
bertindak sesuai dengan nilai dan norma yang ada. Memberi nasehat baik guru piket, wali kelas, guru BK dan guru lainnya ikutb andil ketika melihat siswanya yang berperilaku menyimpang dengan memberi nasehat kepada siswa yang bersangkutan. Membuta surat pernyataan adalah cara yang dilakukan agar siswa tidak mengulangi perilaku menyimpang yang dilakukannya. Pemanggilan orang tua adalah cara yang dilakukan ketika penyimpangan yang dilakukan siswa sudah dianggap berat oleh wali kelas agar orang tua mengetahui perilaku anaknya di sekolah. Hukuman atau sanksi adalah upaya yang dilakukan pihak sekolah agar siswa yang melakukan penyimpangan mendapat efek jera. Hukuman atau sanksi yang diberikan beragam sesuai dengan bentuk penyimpangan yang dilakukan oleh siswa.

\section{KESIMPULAN}

Adapun kesimpulan umum dari penelitian ini adalah remdi sosial yang dilakukan pihak sekolah sudah berjalan dengan baik namun tidak sepenuhnya efektif karena masih ada siswa yang melakukan perilaku menyimpang meskipun sudah diberikan hukuman atau sanksi dari perbuatannya.

Bentuk perilaku menyimpang yang dilakukan oleh siswa SMA Swasta Oikumene Kendari yaitu bolos, absen sekolah, datang terlambat, merokok, main judi, membawa obat terlarang dan mencuri.

Faktor penyebab siswa melakukan perilaku menyimpang yaitu faktor keluarga dimana siswa kurang perhatian orang tua, faktor sekolah atau teman sepermainan siswa terpengaruh ajakan temannya untuk melakukan perilaku menyimpang, dan faktor lingkungan masyarakat atau tempat tinggal juga sangat berpengaruh siswa untuk melakukan perilaku menyimpang.

Remedi sosial yang dilakukan pihak sekolah untuk meminimalisir siswa melakukan perilaku menyimpang yaitu dengan upaya preventif dan upaya represif. Upaya preventif dengan memberikan sosialisasi tentang tata tertib sekolah. 


\section{SARAN}

a. Bagi Sekolah

Remedi sosial yang dilakukan pihak sekolah dalam mengatasi perilaku menyimpang yang dilakukan oleh siswa sudah cukup baik tapi harus di tingkatkan lagi. Sebaiknya kebijakan tentang hukuman yang diterapkan tidak hanya dalam point saja, melainkan lebih tegas agar siswa yang melanggar jera. Dan pihak sekolah harus menjalin kerja sama yang baik dengan orang tua.

b. Bagi Orang Tua

Orang tua harus mampu membina, mendidik, dan menjadi teladan yang baik agar anak menjadi pribadi yang baik dan tidak terjerumus kedalam perilaku menyimpang yang dapat merugikan diri sendiri maupun orang lain.

c. Bagi Siswa

Siswa dapat mempertahankan akhlak yang baik yang ditanamkan dalam pendidikan keluarga maupun sekolah dan selalu berperilaku baik sesuai atauran di dalam ataupun di luar sekolah. Selalu menghindari atau menjauhi perilaku menyimpang karena akan menimbulkan masalah baru.

\section{DAFTAR PUSTAKA}

Ali, Mohammad 2014. Memahami Riset Perilaku Sosial. Yogyakarta: bumi Aksara. Abu Ahmadi, 2004, Sosiologi Pendidikan. Jakarta: Rineka Cipta.

Achmad Alfin. 2004. Perilaku Menyimpang E-Journal On-Line.

Asmani Jamal Ma'mur 2012. Kiat Mengatasi Kenakalan Remaja di Sekolah Yogyakarta: Buku Biru.

Chit, Y. Z. (2020). Prosocial Behaviours of Members from Student Voluntary Clubs in Sagaing University of Education. Indonesian Journal of Social and Environmental Issues (IJSEI), 1(2), 63-68.

Jonaidi, Analisis Sosiologi Terhadap Perilaku Menyimpang Siswa Pada SMA Pembangunan Kabupaten Melinau", dalam ejurnal Sosiatri-Sosiologi, 2013, 1 (3): 11-24 ISSN 0000-0000, ejurnal.sos.fisip-unmul.org. 
Notoatmodjo, Soekidjo. 2003. Pendidikan dan Perilaku Kesehatan. Rineka Cipta

Saparinah Sadli. Persepsi Sosial Mengenai Perilaku Menyimpang. Cet. II; Jakarta: CV. Rajawali, 1983.

Sifyan S, Willis, Remaja dan Masalahnya, (Bandung: Alfabeta, 2008).

Soekanto Soerjono, 1996. Remaja dan Masalah-Masalahnya. Jakarta: Gunung Mulia

Soerjono Soekanto. 1990. Sosiologi Keluarga. Jakarta: Rineka Cipta.

Suhaida, S., Hos., Upe, A. (2018). Pergaulan Bebas di Kalangan Pelajar (Studi Kasus di Desa Masaloka Kecamatan Kepulauan Masaloka Raya Kabupaten Bombana). Jurnal Neo Societal, 3 (2).

Sugiyono. 2009. Memahami Penelitian Kulitatif. Bandung: Alfabeta. 